\title{
Determining hemoglobin reference values in children and teenagers from Sibiu area
}

\section{Stabilirea valorilor de referință pentru hemoglobină la copii şi adolescenți din arealul Sibiu}

\author{
Maria Totan ${ }^{1 *}$, Felicia G. Gligor ${ }^{2}$, Marius Bojita ${ }^{3}$, \\ Camelia Grigore $^{1}$, Cristina Grigore ${ }^{3}$ \\ 1. Pediatric Clinical Hospital, Sibiu - Medical analyses laboratory, \\ 2. Lucian Blaga University Sibiu - Biochemistry Department, \\ 3. University of Medicine and Pharmacy Cluj Napoca-Department of drug analyses
}

\begin{abstract}
Objectives: Reference values are fundamental for the interpretation of laboratory results, which are useful for medical decisions. Each laboratory has to have its own reference values classified according to age groups in order to interpret test results correctly. The expression "normal values" has been replaced by "reference values" because there are various variables that are considered to influence these values. The majority of "reference values" were established over two decades ago using obsolete medical devices and in many cases undefined populations; therefore, nowadays these intervals are not relevant anymore for modern testing technology in clinic laboratories. Methods and materials: The study was carried out at Sibiu Clinic Pediatric Hospital using the laboratory's electronic archive. The samples were taken from hospitalized patients (children and teenagers) and outpatients registered between January and December, 2010. Blood sample testing was performed using the Sysmex XS 1000i analyzer. The reference values for hemoglobin was calculated based on results from a population sample of 9838 patients. The patients were classified into 3 age categories: 1 month - 2 years old; 2 - 10 years old; 10 - 18 years old. Reference values were determined after eliminating outliers, using the robust method to calculate 2.5 and 97.5 percentiles with the SPSS statistical software. Results and Conclusions: The results obtained differed from those specified in the Roche Diagnostics 2004 Guide but were found to be close to the results mentioned in Lothar Thomas's publication, in Laboratory diagnostics.
\end{abstract}

Keywords: children, teenagers, hemoglobin, reference values.

\section{Rezumat}

Scop: Intervalele de referință sunt esențiale pentru interpretarea rezultatelor analizelor medicale, acestea fiind utile în luarea deciziilor medicale. Fiecare laborator trebuie să îşi stabilească propriile intervale de referinţă, clasificate pe grupe de vârstă, pentru a interpreta corect rezultatele testelor efectuate. Termenul de "valori normale" a fost inlocuit cu cel de "valori de referință", pentru că se consideră că există o multitudine de variabile care influentează aceste date. Cele mai multe "valori de referință", au fost stabilite cu două decenii în

*Corresponding author: Totan Maria, Str. Aleea Țesătorilor, Nr. 2, Ap.38, Loc. SIBIU, Jud. SIBIU

Tel.0745133480, E-mail:bancioiumaria@yahoo.com 
urmă, pe instrumente mai vechi şi pe o populație diferită, intervalele nemaifiind relevante în zilele noastre in raport cu tehnologia actuală de testare folosită de către laboratoarele clinice. Materiale şi Metode: Studiul a fost realizat la Spitalul Clinic de Pediatrie Sibiu folosind datele din arhiva electronică a laboratorului. Probele provin de la pacienții (copii şi adolescenți) internați în spital şi cei din ambulatoriu din perioada ianuarie-decembrie 2010. Testarea probelor de sânge a fost făcută cu analizorul Sysmex XS 1000i. Stabilirea intervalelor de referință pentru hemoglobină s-a realizat pe un eşantion de 9838 pacienți. Pacienții au fost împărțiți în 3 clase de vârstă, 1 lună -2 ani; 2-10 ani şi 10-18 ani. Intervalele de referință au fost stabilite, după eliminarea de eşantioane, folosind metoda robustă, pentru a obține percentilele 2,5 şi 97,5 utilizându-se programul SPSS. Rezultate şi concluzii: Rezultatele obținute sunt diferite în comparație cu cele date de Roche Diagnostics 2004 dar mai apropiate de valorile de referință stabilite în manualul lui Lothar Thomas, M.D., in Laboratory diagnostics.

Cuvinte cheie: copii, adolescenți, hemoglobină, intervale de referință.

Received: $8^{\text {th }}$ September 2012; Accepted: $5^{\text {th }}$ February 2013; Published: $4^{\text {th }}$ March 2013.

\section{Introduction}

The expression "reference range" was introduced by Gräsbeck and Saris, in order to replace the old definition of "normal values"(1). Reference ranges provide valuable information in offering a correct interpretation of laboratory results. The concept of reference intervals appears simple but obtaining samples from healthy populations and establishing appropriate ranges is a complex and difficult process. Each laboratory is responsible for ensuring the validity of the reference range issued starting from the test results (2). Reference ranges inspired by external sources must be validated in order to avoid incorrectly classifying an abnormal test result as healthy, or vice versa (3).

Reference ranges cannot be used by a laboratory without being previously checked because:

- the population tested by each laboratory has a different structure, gender, age;

- the equipment and methods used in laboratories may differ.

Various guiding books (e.g. CLSI) give specific recommendations on statistical methods by which reference ranges can be determined (C28-A3) (4).

In clinical medical practice, clinicians use "reference range" to differentiate healthy from ill subjects. The laboratories are required to establish their own reference ranges according to the indi- viduals they analyze, the analyzer and the quantitative methods used (3). In order to achieve this, laboratories use two methods: they either test clinically healthy patients, the reference range representing $95 \%$ of the tested analyte values; or, they use the Hoffmann method, where subjects with minimal pathology are tested, taking into consideration the 5 to 95 percentile of the resulted values (5). The first method is thought to be the best, but it is more difficult to apply as it involves a valid reference group of individuals, healthy patients of various age groups, sex, race and who have to be motivated to participate in the test with their informed consent; thus, the method involves high costs and proper planning (6). The method for determining reference ranges requires 120 healthy subjects (7). Ideally, in establishing the reference range gender, age and ethnic origin have to be taken into account.

In order to establish the reference range, the average and the standard deviation of the data is used which leads to $2.5 \%$ and $97.5 \%$ as reference limits for the analyte of interest (3).

Nowadays, almost all available reference ranges have been set for an adult population and these cannot be referred to in the case of children and teenage patients.

The reference ranges used by our laboratory at the moment have been provided by medical literature, now considered outdated, which was generally based on brief studies carried out with laboratory equipment now considered obsolete (6). 
Laboratories that use literature reference values should check these ranges by taking at least 20 samples from qualified reference patients.

Anemia is defined as a decrease of the circulating hemoglobin below $12 \mathrm{~g} / \mathrm{dl}$. Clinicians ask for the hemoglobin test for most hospitalized children and teenagers or for outpatients.

The erroneous determination of hemoglobin mostly occurs due to the turbidity caused by a large number of white cells or lipemic plasma - this greatly varies depending on the lysis factor (lysis solution used by the device), in the pipe used to determine WBC / Hb. However, there are analyzers that have separate channels for determining hemoglobin and counting WBC. Sysmex XS 1000i uses a stronger lithic reagent thereby solving the problem more easily. There are far fewer cases where the hemoglobin is falsely low than those where the hemoglobin is falsely high (2).

This study was developed out of the need to use our own reference ranges in interpreting test results, considering the fact that the patients tested in our laboratory are mostly children who are between the ages of 1 month and 18 years of age. Hemoglobin is one of the most required tests, and there were enough patients that to take into account in order to establish our own reference range for hemoglobin. Reference values for hemoglobin were established many years ago, on a different population and by using methods and reagents different from those used nowadays.

\section{Materials and Method}

Patient selection, blood sample collection and sample formation have been conducted at the Sibiu Clinic Pediatric Hospital. The study was carried out by analyzing data from samples collected during a year belonging to hospitalized children and teenagers or outpatients. The samples were collected in vacuum containers containing anticoagulant $-\mathrm{K}_{3}$ EDTA, and were tested within 2 hours after collection. All blood samples were collected by venous puncture. Hemoglobin analysis was performed using the Sysmex XS $1000 \mathrm{i}$ analyzer. It uses the non-toxic reagent, Sodium Lauryl Sulfate (SLS). The end product is hemoglobin sulphate, a colored compound, that is measured spectrophotometrically at $\lambda=534 \mathrm{~nm}$.

The Sysmex XS-1000i analyzer is calibrated and checked by using test blood at 3 levels before performing the actual blood analysis. The actual blood tests are carried out only if calibrated within normal parameters. As advised by the manufacturer, the analyzer undergoes maintenance daily, weekly and monthly.

The results used for the study were obtained from the laboratory electronic data archive.

The database consisted of results from 9383 patients that were divided into three categories, namely: 1 month to 2 years old; 2 to 10 years old and 10 to 18 years old. The age groups were classified according to the way the departments of the Pediatric Clinic are structured by children's age groups. We analyzed data from 2894 patients, aged 1 month to 2 years, 4434 patients ,aged 2 to 10 years old and 2510 patients aged 10 to 18 years old.

\section{Statistical Method}

Statistical data analysis used the indirect Hoffman method adapted through Statistical Program For Social Sciences (SPSS) software.

According to the Hoffman method (8), in the first instance, the abnormal values were eliminated. Although the Hoffmann method requires to remove these values by using Chauvenet criteria, which refer to the removal of the values whose probability of occurrence is less than $1 /(2 \mathrm{~N})$, where $\mathrm{N}$ is the number of values worked on and has to be greater than 4 , in this study, all the values smaller than 9 were eliminated at first as pathological and only then Chauvenet criteria were used.

After removing inappropriate values, data were reconsidered and the cumulative frequency was determined. The frequency of a test result was taken as the number of times a result occurs in the data set divided by the total number of results times $100 \%$. 


$$
F_{X_{i}}=\frac{\text { Count }_{X_{i}}}{\text { Count }_{\text {data pool }}} \times 100 \%
$$

The cumulative frequency is:

$$
C F_{X_{i}}=\sum_{k=2}^{i} F_{X_{k}} \text {, ordered by } \mathrm{X}_{\mathrm{i}}
$$

Data were represented graphically (cumulative frequency in relation to the $\mathrm{Hb}$ values) and values corresponding to the linear portion of the graph as well as the maximum deviation were determined by visual assessment.

Subsequently, the best-fitting linear regression $\left(\mathrm{y}_{\mathrm{i}}=\alpha^{*} \mathrm{x}_{\mathrm{i}}+\beta+\varepsilon_{\mathrm{i}}\right)$ equation was determined by least-squares analysis ( $\alpha$ is the slope, $\beta$ is the intercept of the line and $\varepsilon_{\mathrm{i}}$ is the error). The line with the minimum sum of square residual values was identified accordingly.

Maximum and minimum values were determined by solving the equation of the line, taking into consideration the fact that the values had to stay within the 2.5 and 97.5 percentiles.

RImin $=\alpha * 2.5+\beta$ and $\operatorname{RImax}=\alpha * 97.5+\beta$

The reference intervals obtained were then compared to those of Lothar Thomas, Clinical Laboratory Diagnostics, 1998 (9) and Roche Diagnostics, 2004.

\section{Results and Discussions}

The first figure represents the graph for the age group: 1 month to 2 years old. The second figure represents the graph for age group: 2 to 10 years old. The third figure reflects the graph for age group: 10 to 18 years old.

In Table 1 we present the regression functions and Calculated Reference Intervals for hemoglobin by the computerization of the Hoffmann Method for Indirect Estimation of Reference Intervals.

In Table 2 we show a comparison between the Calculated Reference Intervals and the Reference Intervals Reported in the Literature in Lothar Thomas -Clinical Laboratory Diagnostics, 1998.
In Table 3 we show a comparison between the Calculated Reference Intervals and the Reference Intervals Reported by Roche Diagnostics, 2004.

For the age group of 1 month to 2 years the linear regression and regression function presented in Table 1 indicate that the interval for haemoglobin is $9.46-12.79 \mathrm{~g} / \mathrm{dl}$, whereas in both the Lothar Thomas - Clinical Laboratory Diagnostics 1998 Guide and the Roche Diagnostics 2004 Guide the reference interval for this age is reported at 9.2-12.8 $\mathrm{g} / \mathrm{dl}$, therefore we can say that our values are not significantly different and that the values that we have been using are valid for the population at hand.

Concerning the 2 to 10 years age group, with the linear regression and regression function presented in Table 2, our population showed values of $11.57-14.40 \mathrm{~g} / \mathrm{dl}$ that are similar to the reference values of $11.1-14.7 \mathrm{~g} / \mathrm{dl}$ that presented in the Lothar Thomas-Clinical Laboratory Diagnostics 1998 Guide and that we have been using as reference, however the Roche Diagnostics 2004 Guide offer a much larger interval of 10.8$15.6 \mathrm{~g} / \mathrm{dl}$ at this age and therefore in relation to our findings it is more relevant to guide ourselves after the first reference when making interpretations, for it is closer to our specific population.

For adolescents aged 10-18 years, with the linear regression and regression function presented in Table 3, we have found values of 11.83-14.70 $\mathrm{g} / \mathrm{dl}$ and by comparing our results with the reference interval of 11.8-16.8 g/dl stated by Lothar Thomas - Clinical Laboratory Diagnostics 1998 Guide of it can be observed that the upper limit has been found to be lower in the case of adolescents in the Sibiu area, leaving it to be decided if this needs further investigation regarding the statistical significance of the difference found. Nevertheless, the comparison with the Roche Diagnostics 2004 Guide is not possible for the values for this age group provided are divided by gender and this will remain the limitation of the present study than can be tackled if further study will be done on the subject. However, the reference range stated by the Roche Diagnostics 2004 Guide for girls (12.3 - 


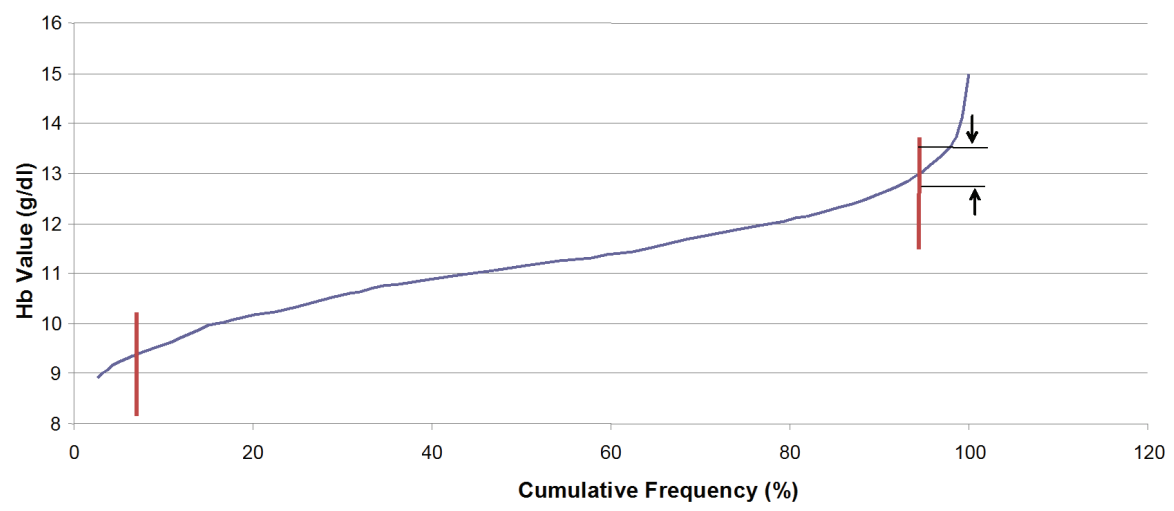

Figure 1. Cumulative frequency of the Hb concentration for age group: 1 month -2 years old

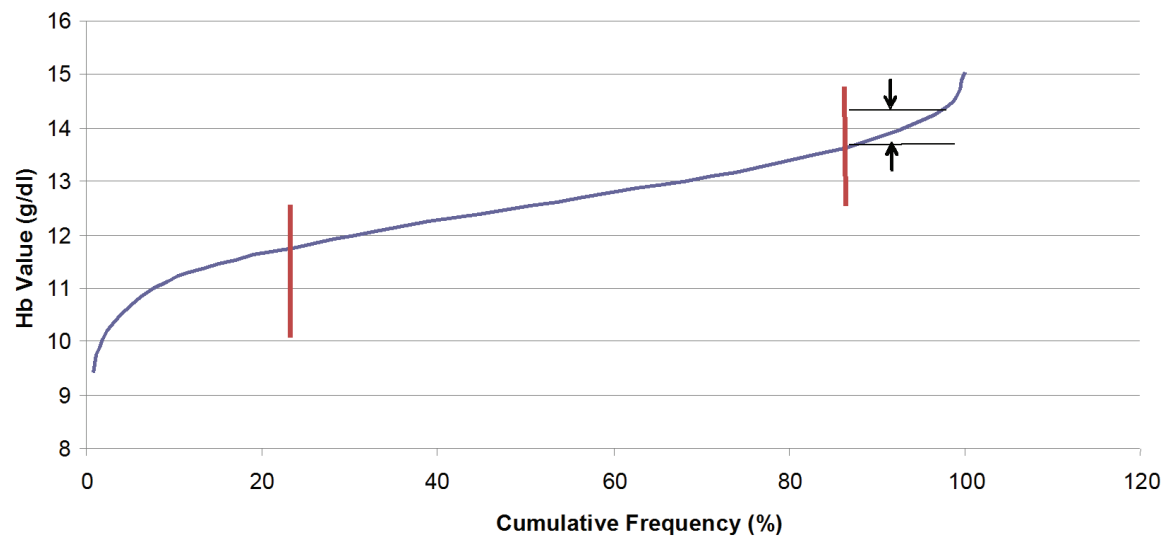

Figure 2. Cumulative frequency of the $\mathbf{H b}$ concentration for age group: 2 years -10 years old

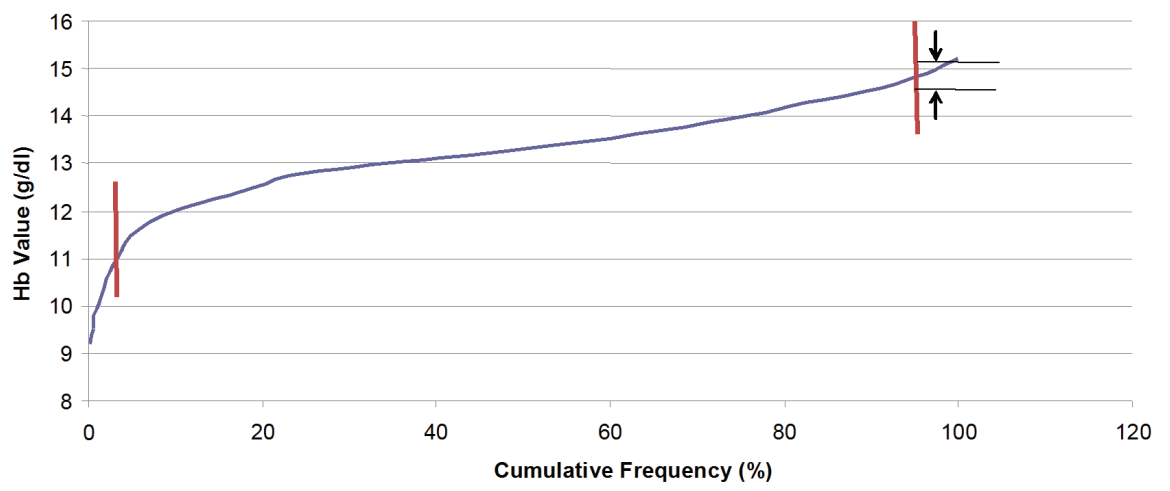

Figure 3. Cumulative frequency of the $\mathrm{Hb}$ concentration for age group: 10 years - 18 years old

$15.3 \mathrm{~g} / \mathrm{dl})$, which are lower than the corresponding range for boys, are higher than the range calculated by us for the entire group $(11.83-14.79 \mathrm{~g} / \mathrm{dl})$.

It is to be stated that, we did not check if the difference between the values we have obtained and those found in literature is statistically relevant because the studies have not been conducted in the same manner, using the same laboratory equipment.

The values obtained through our study have to be validated and only then can be used in 
Table 1. Regression Functions and Calculated Reference Intervals for Haemoglobin by the Computerization of the Hoffmann Method for Indirect Estimation of Reference Intervals

\begin{tabular}{cccc}
\hline Age Groups & Linear Range $(\boldsymbol{\%})$ & Regression Function & Reference Intervals \\
\hline 1 month -2 years & $10.75-93.30$ & $0.035 x+9.38$ & $9.46-12.79$ \\
$2-10$ years & $28.14-89.72$ & $0.0298 x+11.05$ & $11.57-14.40$ \\
$10-18$ years & $8.56-96.43$ & $0.0311 x+11.76$ & $11.83-14.79$ \\
\hline
\end{tabular}

Table 2. Comparison between the Calculated Reference Intervals for Haemoglobin and the Reference Intervals Reported in the Literature, Lothar Thomas - Clinical Laboratory Diagnostics, 1998

\begin{tabular}{ccc}
\hline Age Groups & $\begin{array}{c}\text { Calculated RI } \\
\text { (Lower - Upper) }\end{array}$ & $\begin{array}{c}\text { Reported RI } \\
\text { (Lower -Upper) }\end{array}$ \\
\hline 1 month -2 years & $9.46-12.79$ & $9.2-12.8$ \\
$2-10$ years & $11.57-14.40$ & $11.1-14.7$ \\
$10-18$ years & $11.83-14.79$ & $11.8-16.8$ \\
\hline
\end{tabular}

Table 3. Comparison between the Calculated Reference Intervals for Haemoglobin and the Reference Intervals Reported Roche Diagnostics, 2004

\begin{tabular}{ccc}
\hline Age Groups & $\begin{array}{c}\text { Calculated RI } \\
\text { (Lower - Upper) }\end{array}$ & $\begin{array}{c}\text { Reported RI, Roche Diagnostics, 2004 } \\
\text { (Lower - Upper) }\end{array}$ \\
\hline 1 month -2 years & $9.46-12.79$ & $9.2-12.8$ \\
$2-10$ years & $11.57-14.40$ & $10.8-15.6$ \\
$10-18$ years & $11.83-14.79$ & $>10$ years \\
& & F:12.3-15.3 \\
& & M:14.0-17.5 \\
\hline
\end{tabular}

our daily work. The validation process needs healthy volunteers and because they are of a young age informed consent is also required. These limitations need to be solved in order to use the results and to proceed with the study.

\section{Conclusions}

For the age group 1 month -2 years old, we obtained almost identical values to the ones stated in the literature, in the Lothar Thomas book, Clinical Laboratory Diagnostics1998, as well as in the Reference Intervals volume of Roche Diagnostics Company, 2004.

With regard to the $2-10$ years age group, our study presented a narrower reference interval, having a greater lower limit and a smaller upper limit in comparison to the study led by Roche Diagnostics, 2004.

In relation to $10-18$ years age group, our study showed differences from the limits presented by Roche Diagnostics, 2004.

The reference intervals presented in our study are closer to those shown in Lothar Thomas book from 1998 than to the ones obtained through Roche Diagnostics study in 2004.

The reference ranges that we have obtained are specific for the population aged 1 month to 18 years in the Sibiu region as well as for the method used in our laboratory. Although similar to the ones stated in the Lothar Thomas publication, they differ from those specified in the Roche Diagnostics 2004 Guide therefore further emphasizing the need for establishing refer- 
ence ranges individualized for our laboratory through a study using a controlled population. The laboratories that will import these results have to validate the method before using them.

\section{References}

1. Guidi G.C., Lippi G., Solero G. P., Poli G., Plebani M., Managing transferability of laboratory data- Clin Chim Acta, 2006, 374, 57-62.

2. Jung B., Adeli K., Clinical laboratory reference intervals in pediatrics: The CALIPER initiative - Clin Biochem, 42, 2009, 1589-1595.

3. Kulasingam V., Jung P.B., Ivan M. B., Baradaran S., Chan M. K., Aytekin M., et al, Pediatric reference intervals for 28 chemistries and immunoassays on the Roche Cobas ${ }^{\circledR} 6000$ analyzer-A CALIPER pilot study Clin Biochem, 2010, 43, 1040-1045.
4. Clinical and Laboratory Standard Institute. Reference and Selected Proceeding for the Quantitative Determination of Hemoglobin in Blood; Approved Standard-Third Edition. CLSI, FDA. Wayne, Pennsylvania : s.n., 2000. 156238-425-2.

5. Barbara J. B., Blood Cells. A Practical Guide. s.l. : Blackwell Science, 2002, 181-183.

6. Christensen D. R., Henry E., Jopling J., Wiedmeier E. S., The CBC: Reference Ranges for Neonates - Semin Perinatol, 2009, 33, 3-11.

7. Katayev A., Balciza C., Seccombe W. D., Establishing Referance Intervals for Clinical Laboratory Test Results - Am J Clin Pathol, 2010, 130, 180-186.

8. Hoffmann RG. Statistics in the practice of medicine. JAMA.1963;185:864-873.

9. Lothar T., - Hemoglobins, Clinical Laboratory Diagnostics, Use and Assesment of Clinical Laboratory Results - Frankfurt/Main: TH Books Verlagsgesellschaft $\mathrm{mbH}, 1998:$ 475-476. 